\title{
Prevalence and potential factors associated with probable sleep or awake bruxism and dentin hypersensitivity in undergraduate students
}

\author{
Prevalência e potenciais fatores associados ao provável bruxismo do sono e em \\ vigília e hiperestesia dentinária cervical em universitários \\ Neusa Barros DANTAS-NETA ${ }^{a}$, Joseany Barbosa LAURENTINOa, \\ Carlos Henrique de Carvalho e SOUZA ${ }^{\text {a }}$, Danila Lorena NUNES-DOS-SANTOS ${ }^{\text {, }}$ \\ Regina Ferraz MENDES ${ }^{a}$, Raimundo Rosendo PRADO-JÚNIOR ${ }^{a}$ \\ ${ }^{a}$ Centro de Ciências da Saúde, \\ UFPI - Universidade Federal do Piauí, Teresina, PI, Brasil
}

\begin{abstract}
Resumo
Objetivo: Mensurar a prevalência de provável bruxismo do sono e em vigília e de hiperestesia dentinária cervical de estudantes universitários e verificar os sintomas a eles associados. Metodologia: Este é um estudo transversal, cujo diagnóstico de provável bruxismo foi realizado pelo relato dos estudantes em ranger e/ou apertar os dentes durante o sono e em vigília combinado com o diagnóstico clínico de desgaste dentário e dor da musculatura do masseter à palpação. O diagnóstico de hipersensibilidade dentinária cervical foi realizado por testes de sensibilidade ao toque com sonda exploradora e a jato de ar da seringa tríplice. A amostra consistiu de 306 universitários entre 19 a 35 anos. Os dados foram armazenados e analisados no programa SPSS v.15.0 for Windows. Resultado: A prevalência de provável bruxismo foi de $34,3 \%$, não havendo predominância entre os gêneros. O provável bruxismo em vigília foi o mais predominante (61,9\%), ocorrendo principalmente quando o indivíduo estava em estado de concentração $(63,1 \%)$. Não houve uma associação entre provável bruxismo do sono e em vigília e hiperestesia dentinária $(\mathrm{p}=0,195)$. Os indivíduos com provável bruxismo do sono possuíram maior chance de acordar com dor nos músculos da face (OR=14,14, IC95\% 5,06-39,55) e com provável bruxismo em vigília maior chance de cansaço muscular facial ao mastigar ou falar por muito tempo (OR=2,88, IC95\% 1,53-5,43) e dor nos músculos da face ao acordar $(\mathrm{OR}=5,31$, IC95\% 1,93-14,62). Conclusão: A prevalência de provável bruxismo foi $34,3 \%$ e de HDC 57,8\%, com 22,2\% destes também apresentando provável bruxismo, mas sem associação estatística. Indivíduos com provável bruxismo tendem a ter maior risco de apresentar dores faciais ao acordar e cansaço muscular facial ao falar e mastigar por muito tempo. Não houve associação entre provável bruxismo do sono e em vigília e hipersensibilidade dentinária cervical.
\end{abstract}

Descritores: Bruxismo; sensibilidade da dentina; prevalência; análise multivariada.

\begin{abstract}
Objective: To measure the prevalence of probable sleep or awake bruxism and cervical dentin hypersensitivity of undergraduate students and to determine the symptoms associated with these conditions. Methodology: This was a cross-sectional study. A diagnosis of probable bruxism was reached when students reported clenching or grinding of the teeth during sleep and/or wakefulness, and when they also presented some of the signs and symptoms of bruxism and masseter muscle pain on palpation. Cervical dentinal hypersensitivity was diagnosed by testing for sensitivity to pain in the cervical region of the teeth. Pain was triggered either by touch (using a \#5 probe) or by an air jet spray. The sample consisted of 306 university students aged between 19 and 35 years old. The data were stored and analysed using SPSS software, version 15.0 for Windows. Result: The prevalence of probable bruxism was $34.3 \%$, with no predominance regarding sex. Probable awake bruxism was more prevalent (61.9\%), mostly occurring when the individual reported being in a state of mental concentration (63.1\%). There was no association between probable sleep or awake bruxism and dentin hypersensitivity $(\mathrm{p}=0.195)$. Individuals with probable sleep bruxism had increased odds of having muscular pain in the face upon waking $(\mathrm{OR}=14.14,95 \% \mathrm{CI} 5.06-39.55)$, and those with probable awake bruxism had a increased odds of having facial muscle fatigue when chewing or talking for a long time ( $\mathrm{OR}=2.88,95 \% \mathrm{CI} 1.53-5.43)$ and muscular pain in the face upon waking ( $\mathrm{OR}=5.31,95 \% \mathrm{CI} 1.93-14.62)$. Conclusion: The prevalence of probable bruxism was $34.3 \%$ and that of HDC was $57.8 \%$, with $22.2 \%$ of these subjects also showing probable bruxism. Individuals with probable bruxism tended to have a higher odds of facial pain when they awakened and when chewing or talking for long periods. There were no associations between probable sleep and awake bruxism and cervical dentin hypersensitivity.
\end{abstract}

Descriptors: Bruxism; dentin sensitivity; prevalence; multivariate analysis. 


\section{INTRODUCTION}

Bruxism is a repetitive muscular activity characterised by clenching or grinding of the antagonist teeth and/or of the propulsion mandible. Bruxism has two distinct circadian manifestations that can occur during sleep (sleep bruxism) or while awake (awake bruxism). Despite an abundance of techniques, reliable and validated diagnostic tools for bruxism are scarce. Thus, a subdivision of bruxism has recently been proposed. Possible bruxism is rated so that a diagnosis can be obtained only by self-reporting through questionnaires and/or a clinical history. Probable bruxism is diagnosed by self-reporting combined with clinical examination. Definitive bruxism is diagnosed with a combination of self-reporting, clinical examination and polysonography ${ }^{1}$.

According to the American Sleep Disorders Association (ASDA), bruxism could affect $85-90 \%$ of the population ${ }^{2}$. One study estimated that $20 \%$ of the population has bruxism during wakefulness and $10 \%$ during sleep, occurring most frequently in adolescents and declining with age. Some studies have shown that there is no difference between sexes ${ }^{3,4}$, while others have reported a higher prevalence in women ${ }^{5,6}$.

Bruxism increases the incidence of high magnitude force on the masticatory system. As a consequence, there are signs such as muscle pain, temporomandibular joint pain and pain in the supporting structures of the teeth, as well as changes in the enamel and dentin ${ }^{7}$. Some of the signs of bruxism include widely disseminated wear, cracks or fractures of the teeth and restorations. Tooth wear is considered a visible sign of bruxism, and it can have quite rapid progression ${ }^{7}$. In addition, bruxism has also been strongly associated with cervical dentin hypersensitivity $(\mathrm{CDH})^{8,9}$.

The aetiology of bruxism is unknown. Awake bruxism is associated with stress and anxiety ${ }^{10}$, while sleep bruxism is associated with sleep arousal, cardiac sympathetic-autonomous activation, a genetic predisposition, neurochemical factors, psychosocial components, exogenous factors and comorbidities, such as sleep apnoea ${ }^{10,11}$.

For many individuals, the beginning of academic life marks the beginning of adulthood, with its responsibilities and demands. At this time, people are exposed to high levels of psychological stress due to the demands of their education. This time can be ripe for the development of bruxism, so the target population of this study was undergraduate students.

This study aimed to measure the prevalence of probable sleep and awake bruxism and of $\mathrm{CDH}$ and to determine the signs and socioeconomic variables most commonly associated with bruxism in undergraduate students.

\section{METHODOLOGY}

This cross-sectional study had an unintentional sample that consisted of 378 volunteer undergraduate students between 18 and 35 years old. This sample size was calculated by considering that 54,534 people were enrolled in higher education in the city of Teresina, Piauí, in $2009^{12}$, and the estimated prevalence of bruxism was $45 \%{ }^{13}$, with a confidence level of $95 \%$ and $5 \%$ error. All participants agreed to sign an informed consent form (ICF), and the study was approved by the Committee Ethics and Research of the Federal University of Piauí (UFPI - Protocol: 0158.0.045.000-09).

The inclusion criteria were that the participants be older than 18 years and be undergraduate students. The exclusion criteria included the use of braces, systemic or psychological disorders, having undergone coronary scraping, bleaching of the teeth or the use of some method to treat dentin hypersensitivity in the six months before data collection.

Data collection was performed by a single examiner in a clinical setting. During anamnesis, a form was completed, and data were recorded, including patient identification, social and demographic characteristics, information about the general state of health, parafunctional habits and reports of headache, tiredness and muscle or joint pain.

First, the individual completed a questionnaire about the presence of sleep or awake bruxism within the 4 weeks prior to the questionnaire. Bruxism could be confirmed when observed by a spouse, roommate or family member during sleep or when awake ${ }^{10,14}$. Then, a physical examination was performed to investigate the presence of pain on palpation of the masseter muscle and to analyse the clinical presence of wear on the teeth, characterised by smooth, glossy surfaces and sharp edges on the anterior or posterior teeth during protrusive movements and laterality of the mandible ${ }^{10,14}$. The diagnosis of probable bruxism was made when there was a self-reported habit of clenching or grinding of the teeth during sleep or when awake, combined with the presence of clinical signs, such as tooth wear and pain of the masseter muscles on palpation.

The diagnosis of $\mathrm{CDH}$ was based on the presence of two stimuli: painful sensitivity to tactile stimulation (tip of the explorer being used in the mesial-distal direction in the cervical region of each tooth) or painful sensitivity to an evaporative stimulus (air jet triple syringe for 2-5 seconds, directed at the buccal surface of the cervical region of each tooth at a distance of $5 \mathrm{~mm})^{15}$. The diagnosis of $\mathrm{CDH}$ was considered when at least one tooth was sensitive during the exam.

The data were analysed using Statistical Package for Social Sciences (SPSS, Chicago, IL, USA.), version 15.0. We conducted bivariate and multivariate analyses to assess the association between bruxism and the independent variables of the study. In the bivariate analysis, we used the chi-square test and Fisher's exact test, considering $\mathrm{p}$ values $\leq 0.05$ to be statistically significant.

For multivariate analysis, we performed multinomial logistic regression using the Wolf method to obtain estimates (odds ratio) and confidence intervals adjusted for variables of trust. We used this method because it allowed for the calculation of odds ratios, considering a dependent with more than two categories of variables. Each category was compared to a reference in one process. 
In the present study, the analysis was performed by comparing the individuals who did not have bruxism (reference category) with those who had sleep or awake bruxism. The criterion for the inclusion of variables in the logistic model was a $p$ value $\leq 0.20$ in the bivariate analysis. The criterion for including the remaining variables in the model was $\mathrm{p}<0.05$.

\section{RESULT}

A total of 378 students agreed to schedule an appointment at the dental clinic of the university to participate in the study; however, 306 (81.0\%) attended and participated. The others failed to appear for two appointments (Figure 1).

The majority of students were single and female and had family incomes 1-6 times the minimum wage (Table 1). The prevalence of probable bruxism was $34.3 \%$. Probable awake bruxism was the most prevalent type (61.9\%), occurring mainly during moments of mental concentration (63.1\%), followed by moments of emotional tension (nervousness: $20 \%$; anxiety and stress: $16.9 \%)$. The prevalence of CHD was $57.8 \%$ among the students, and $22.2 \%$ of them had probable sleep or awake bruxism. The teeth most affected by HDC were the premolars in the buccal surfaces (35.9\%), followed by the incisors $(32.9 \%)$, molars (17.9\%) and canines (13.3\%).

Associations between sleep or awake bruxism and signs included a feeling of headache on awakening $(\mathrm{p}=0.014)$, facial muscle tiredness when chewing or talking for a long time $(\mathrm{p}<0.001)$ and pain in the muscles of the face upon awakening $(\mathrm{p}<0.001)$. However, no associations with sex $(\mathrm{p}=0.263)$ or CDH ( $\mathrm{p}=0.195)$ (Table 1) were observed.

An analysis of the combined influence of these factors, adjusted by multinomial logistic regression, showed that individuals with probable sleep bruxism were 14.14 times more likely to have pain in the muscles of the face on awakening (95\% CI $=5.06-39.55$, $\mathrm{p}<0.001$ ), and those with probable awake bruxism were 2.88 times more likely to have muscular fatigue when chewing or talking extensively (95\% CI $=1.53-5.43, \mathrm{p}=0.001)$ and 5.31 times more likely to have pain in the muscles of the face on awakening $(95 \% \mathrm{CI}=1.93-14.62, \mathrm{p}=0.001)($ Table 2$)$.

\section{DISCUSSION}

The prevalence of probable bruxism measured in this study was $34.3 \%$, with awake bruxism more prevalent $(21.2 \%)$ than other forms (13.1\%). Few studies have reported the prevalence of bruxism in undergraduate students. We know that this prevalence is important because undergraduate students are exposed to stress due to their academic and personal responsibilities, which tend to increase at this stage of life.

The measured prevalence of bruxism in adults has had variable results. A literature review concluded that the prevalence of awake bruxism in the adult population was $20 \%$, while that of sleep bruxism was $8 \%^{10}$. Another study determined the prevalence of adults with sleep bruxism to be $14 \%$ and those with awake bruxism to be $31 \%{ }^{16}$. These results were lower than those measured in our study but showed that awake bruxism was more prevalent than sleep bruxism. However, unlike the present study, the previous authors used only self-reports (without clinical examination) based on the memories of individuals and excluded subjects who were not aware of their bruxism; polysomnography and electromyography are the required exams for the gold standard of a final diagnosis of bruxism, but using these tests for large sample sets is expensive ${ }^{10,16}$. Because of this limitation, these tests were not used.

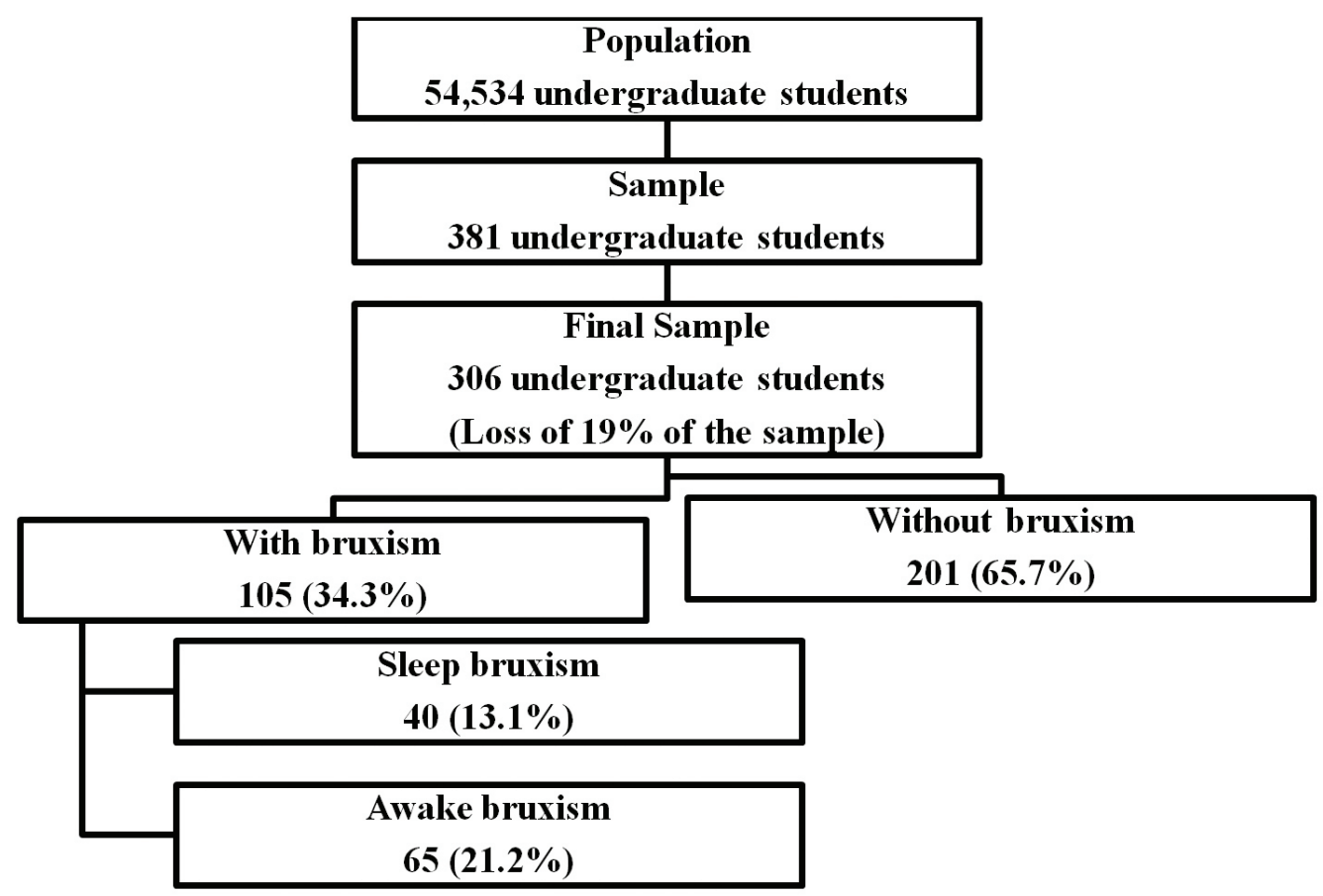

Figure 1. Flow chart demonstrating the study methodology. 
Table 1. Associations between sleep and awake bruxism and potential risk factors $(\mathrm{n}=306)$

\begin{tabular}{|c|c|c|c|c|c|c|}
\hline & & \multicolumn{2}{|c|}{ Bruxism } & \multirow{2}{*}{$\begin{array}{l}\text { Without brux- } \\
\text { ism } \\
\mathrm{N}(\%)\end{array}$} & \multirow{2}{*}{$\begin{array}{l}\text { Total } \\
\text { N (\%) }\end{array}$} & \multirow[b]{2}{*}{$p$ value } \\
\hline & & $\begin{array}{l}\text { Sleep } \\
\text { N (\%) }\end{array}$ & $\begin{array}{l}\text { Awake } \\
\text { N (\%) }\end{array}$ & & & \\
\hline \multirow{2}{*}{ Sex } & Male & $18(12.1)$ & $30(20.1)$ & $101(67.8)$ & $149(100)$ & $0.748^{+}$ \\
\hline & Female & $22(14.0)$ & $55(22.5)$ & $100(63.7)$ & $157(100)$ & \\
\hline \multirow{3}{*}{ Age group } & $<20$ years & $38(13.0)$ & $62(21.2)$ & $193(65.9)$ & $293(100)$ & $0.930^{*}$ \\
\hline & 20-25years & $1(12.5)$ & $2(25.0)$ & $5(62.5)$ & $8(100)$ & \\
\hline & $>25$ years & $1(20.0)$ & $1(20.0)$ & $3(60.0)$ & $5(100)$ & \\
\hline \multirow{4}{*}{ Family income } & $\leq 3 \mathrm{MW}$ & $12(12.6)$ & $18(18.9)$ & $65(68.4)$ & $95(100)$ & $0.954^{+}$ \\
\hline & 4 to $6 \mathrm{MW}$ & $14(14.9)$ & $18(19.1)$ & $62(66.0)$ & $94(100)$ & \\
\hline & 7 to $10 \mathrm{MW}$ & $8(13.1)$ & $14(23.0)$ & $39(63.9)$ & $61(100)$ & \\
\hline & $>10 \mathrm{MW}$ & $6(14.3)$ & $11(26.2)$ & $25(59.5)$ & $42(100)$ & \\
\hline \multirow{2}{*}{ Headache upon awakening } & Yes & $17(23.0)$ & $15(20.3)$ & $42(56.8)$ & $74(100)$ & $0.014^{+}$ \\
\hline & No & $23(9.9)$ & $50(21.6)$ & $159(68.5)$ & $232(100)$ & \\
\hline \multirow{2}{*}{$\begin{array}{l}\text { Facial muscle tiredness } \\
\text { when chewing or talking for } \\
\text { a long time }\end{array}$} & Yes & $16(19.3)$ & $29(34.9)$ & $38(45.8)$ & $83(100)$ & $<0.001^{+}$ \\
\hline & No & $23(9.9)$ & $50(21.6)$ & $159(68.5)$ & $232(100)$ & \\
\hline \multirow{2}{*}{$\begin{array}{l}\text { Pain in the muscles of the } \\
\text { face upon awakening }\end{array}$} & Yes & $16(19.3)$ & $29(34.9)$ & $38(45.8)$ & $83(100)$ & $<0.001^{+}$ \\
\hline & No & $24(10.8)$ & $36(16.1)$ & $163(73.1)$ & $223(100)$ & \\
\hline \multirow[b]{2}{*}{ General health } & With problems & $9(14.1)$ & $15(23.4)$ & $40(62.5)$ & $64(100)$ & $0.831^{+}$ \\
\hline & $\begin{array}{l}\text { Without prob- } \\
\text { lems }\end{array}$ & $31(12.8)$ & $50(20.7)$ & $161(66.5)$ & $242(100)$ & \\
\hline \multirow{2}{*}{$\begin{array}{l}\text { Cervical dentin hypersen- } \\
\text { sitivity }\end{array}$} & Yes & $25(14.1)$ & $43(24.3)$ & 109 (61.6) & $177(100)$ & $0.195^{+}$ \\
\hline & No & $15(11.6)$ & $22(17.1)$ & $92(71.3)$ & $129(100)$ & \\
\hline \multirow{2}{*}{ Other habits } & Yes & $17(13.0)$ & $23(17.6)$ & $91(69.5)$ & $131(100)$ & $0.375^{+}$ \\
\hline & No & $23(13.1)$ & $42(24.0)$ & $110(62.9)$ & $175(100)$ & \\
\hline
\end{tabular}

${ }^{\star}$ Fisher's exact test; + chi-square test.

In this study, more than half of the sample was diagnosed with $\mathrm{CDH}$, and the teeth most affected were the premolars. Lower prevalence values were found in Nigerian university students $(33.8 \%)^{17}$ and in Turkish students $(8.4 \%)^{18}$. The age range of our sample coincided with the peak prevalence for $\mathrm{CDH}$ in a study that evaluated the 18-44 age group ${ }^{19}$, but it fell short of the range of the peaks of two other studies: $30-39$ years $^{20}$ and 50-59 years ${ }^{21}$. Thus, the difference between age groups may have contributed to the different prevalence rates between the studies.

In another study, researchers found that the group of upper teeth and molars had a greater prevalence of $\mathrm{CDH}$, differing from this study ${ }^{22}$. The group of teeth most affected by CDH can vary between studies, according to the design, the age of the sample, the presence of systemic or local disease, dietary habits, oral hygiene and the number of teeth. Thus, a limitation of this study was that we did not examine the factors associated with $\mathrm{CDH}$ because we only sought the existence of a simple association between the presence of bruxism and $\mathrm{CDH}$. However, this aspect might be the target of future investigations because the multifactorial nature of the two investigated phenomena raised suspicions that could not be addressed here due to these limitations.

Age, sex, alcohol consumption, stress, marital status and nature of work have been considered as predisposing factors of bruxism $^{23,24}$. In our sample, there were no associations between bruxism and socioeconomic factors or the sex of the individual. This lack of association with sex was also found in other studies with similar sample characteristics ${ }^{3,4}$. Alcoholism and stress were not investigated. Thus, we can attribute the lack of associations with socioeconomic factors and sex to the young age of the sample.

There were no associations between overall health conditions and bruxism in our sample. This finding diverged from the literature, which indicated that general health problems could cause bruxism ${ }^{25}$. This discrepancy may be due to the different criteria used for the diagnosis of bruxism or because of the relative health of the study sample due to its age.

Bruxism has the potential to trigger HDC by causing tooth wear and dentin exposure ${ }^{26}$. Therefore, we investigated the 
Table 2. Crude and adjusted odds ratio (OR) by multinomial logistic regression analysis of variables associated with the probable sleep and awake bruxism

\begin{tabular}{|c|c|c|c|c|c|c|}
\hline & & & $\begin{array}{c}\text { OR not } \\
\text { adjusted } \\
(95 \% \mathrm{CI})\end{array}$ & p value & $\begin{array}{l}\text { OR adjusted } \\
(95 \% \mathrm{CI})\end{array}$ & $p$ value \\
\hline \multirow{8}{*}{$\begin{array}{l}\text { Probable sleep } \\
\text { bruxism }\end{array}$} & \multirow[t]{2}{*}{ Has a headache upon awakening } & Yes & $\begin{array}{c}2.46 \\
(1.05-5.77)\end{array}$ & 0.035 & $\begin{array}{c}1.77 \\
(0.78-3.96)\end{array}$ & 0.166 \\
\hline & & No & 1 & & 1 & \\
\hline & \multirow{2}{*}{$\begin{array}{l}\text { Facial muscle tiredness when } \\
\text { chewing or talking for a long time }\end{array}$} & Yes & $\begin{array}{c}2.85 \\
(1.38-5.90)\end{array}$ & 0.003 & $\begin{array}{c}1.64 \\
(0.71-3.78)\end{array}$ & 0.244 \\
\hline & & No & 1 & & 1 & \\
\hline & \multirow{2}{*}{$\begin{array}{l}\text { Pain in the muscles of the face } \\
\text { upon awakening }\end{array}$} & Yes & $\begin{array}{c}18.47 \\
(6.90-49.43)\end{array}$ & $<0.001$ & $\begin{array}{c}14.14 \\
(5.06-39.55)\end{array}$ & $<0.001$ \\
\hline & & No & 1 & & 1 & \\
\hline & \multirow[t]{2}{*}{ Cervical dentin hypersensitivity } & Yes & $\begin{array}{c}0.85 \\
(0.37-1.93)\end{array}$ & 0.703 & $\begin{array}{c}0.97 \\
(0.45-2.10)\end{array}$ & 0.945 \\
\hline & & No & 1 & & 1 & \\
\hline \multirow{8}{*}{$\begin{array}{l}\text { Probable awake } \\
\text { bruxism }\end{array}$} & \multirow{2}{*}{ Has a headache upon awakening } & Yes & $\begin{array}{c}1.13 \\
(0.58-2.21)\end{array}$ & 0.709 & $\begin{array}{c}0.77 \\
(0.37-1.61)\end{array}$ & 0.484 \\
\hline & & No & 1 & & 1 & \\
\hline & \multirow{2}{*}{$\begin{array}{l}\text { Facial muscle tiredness when } \\
\text { chewing or talking for a long time }\end{array}$} & Yes & $\begin{array}{c}3.45 \\
(1.89-6.31)\end{array}$ & $<0.001$ & $\begin{array}{c}2.88 \\
(1.53-5.43)\end{array}$ & 0.001 \\
\hline & & No & 1 & & 1 & \\
\hline & \multirow{2}{*}{$\begin{array}{l}\text { Pain in the muscles of the face } \\
\text { upon awakening }\end{array}$} & Yes & $\begin{array}{c}6.92 \\
(2.63-18.24)\end{array}$ & $<0.001$ & $\begin{array}{c}5.31 \\
(1.93-14.62)\end{array}$ & 0.001 \\
\hline & & No & 1 & & 1 & \\
\hline & \multirow{2}{*}{ Cervical dentin hypersensitivity } & Yes & $\begin{array}{c}1.64 \\
(0.92-2.95)\end{array}$ & 0.091 & $\begin{array}{c}1.37 \\
(0.74-2.52)\end{array}$ & 0.315 \\
\hline & & No & 1 & & 1 & \\
\hline
\end{tabular}

Note: Values are based on reference individuals that did not demonstrate bruxism.

association between bruxism and cervical dentin hypersensitivity. This study did not find an association between $\mathrm{CDH}$ and probable sleep or awake bruxism, although their prevalence was not casual. This strong association was observed in other studies in which individuals with $\mathrm{CDH}$ were 3.85 times more likely to have bruxism. Moreover, there was also an association between CHD and gastroesophageal reflux and with the frequency and force of teeth brushing ${ }^{19,22}$. The age difference between previous studies and the present work (young adults, adults and seniors) might explain the difference in the results.

In this study, probable sleep bruxism was associated with increased odds of awakening with pain in the muscles of the face, while probable awake bruxism was associated with increased odds of having facial muscle fatigue when chewing or talking extensively and pain in the muscles of the face upon awakening. In a German study, researchers found strong associations of sleep bruxism with pain or tension in the muscles of the face upon awakening and articular noises and associations of awake bruxism with orofacial pain and articular noises ${ }^{27}$.
In Brazil, a strong association has been shown among sleep bruxism, headache, facial pain, facial muscle fatigue and dental pain $^{28}$ because bruxists present with pain in the masticatory muscles as a result of prolonged contractions and hypertonic muscles. Thus, blood flow to the muscle tissue decreases, causing accumulation of metabolic products, thus causing pain ${ }^{3}$.

However, a pilot study involving diagnostic standards for the confirmation of bruxism revealed no association between this habit and pain upon awakening. Thus, further studies with gold standard diagnoses are necessary to determine whether the signs of pain in the muscles of the face upon awakening or following extensive talking or chewingare associated with bruxism ${ }^{29}$.

Currently, there is evidence that psychological factors could play an important role in the aetiology of bruxism ${ }^{30}$. However, this aspect was not studied here. Our results are important because they revealed the presence of bruxism in undergraduate students and, despite the fact that a convenience sample was recruited, the subjects were recruited voluntarily. Thus, a randomly recruited sample would be important to evaluate a psychological factors. 
A thorough clinical examination is essential for the diagnosis of bruxism. Diagnosis is the first stage of a complex treatment plan that aims to limit the damage that this habit causes, which can be devastating for the stomatognathic system of the individual.

\section{CONCLUSION}

The prevalence rates of probable sleep and awake bruxism and $\mathrm{CDH}$ were high. Students with probable sleep bruxism were more likely to awaken with pain in the muscles of the face, while those with awake bruxism had an increased the odds of having facial muscle fatigue when chewing or talking extensively, as well as pain in the muscles of the face upon awakening. There were no associations between sleep and awake bruxism and CDH.

\section{ACKNOWLEDGEMENTS}

The authors thank Denis Barbosa Fonseca (a graduate student in Dentistry, Federal University of Piauí) for assistance as an annotator during the data collection. The Scientific Initiation Program of UFPI enabled the study, and Jonathan Spottiswoode assisted by translating the abstract of this article.

\section{REFERENCES}

1. Lobbezoo F, Ahlberg J, Glaros AG, Kato T, Koyano K, Lavigne GJ, et al. Bruxism defined and graded: an international consensus. J Oral Rehabil. 2013 Jan; 40(1): 2-4. PMid:23121262. http://dx.doi.org/10.1111/joor.12011

2. American Academy of Sleep Medicine. International classification of sleep disorders, revised: diagnostic and coding manual. Chicago: American Academy of Sleep Medicine; 2001.

3. Tosato JP, Caria PHF. Prevalence of TMD in different age levels. RGO - Rev Gaúcha Odontol. 2008; 54(3): 221-4.

4. Fissmer JFW, Garanhani RR, Sakae TM, Traebert JL, Soar Filho EJ. Association between anxiety and bruxism in dental students. ACM Arq Catarin Med. 2008; 7(1): 25-9.

5. Ruela ACC, Mattos MGC, Ruela RS, Bezzon OL, Ribeiro RF. Prevalence of bruxism in 277 patients with temporomandibular disorders. RPG: Rev Pos-Grad. 2001; 8(1): 70-5.

6. Manfredini D, Landi N, Romagnoli M, Bosco M. Pscychic and occlusal factors in bruxers. Aust Dent J. 2004; 49(2): 84-9. PMid:15293819. http://dx.doi.org/10.1111/j.1834-7819.2004.tb00055.x

7. Magallón EC, Parrochia JPS. Bruxismo. Bol Hosp San Juan de Dios. 2007; 54(4): 191-7.

8. Ommerborn MA, Schneider C, Giraki M, Schafer R, Singh P, Franz M, et al. In vivo evaluation of noncarious cervical lesions in sleep bruxism subjects. J Prosthet Dent. 2007; 98: 150-8. http://dx.doi.org/10.1016/S0022-3913(07)60048-1

9. Scaramucci T, de Almeida Anfe TE, da Silva Ferreira S, Frias AC, Sobral MA. Investigation of the prevalence, clinical features, and risk factors of dentin hypersensitivity in a selected Brazilian population. Clin Oral Investig. 2013 Jun 6. [Epub ahead of print]. PMid:23740320.

10. Lavigne GJ, Khoury S, Abe S, Yamaguchi T, Raphael K. Bruxism physiology and pathology: an overview for clinicians. J Oral Rehabil. 2008 Jul; 35(7): 476-94 PMid:18557915. http://dx.doi.org/10.1111/j.1365-2842.2008.01881.x

11. Carra MC, Huynh N, Lavigne G. Sleep bruxism: a comprehensive overview for the dental clinicial interested in sleep medicine. Dent Clin North Am. 2012 Apr; 56(2): 387-413. PMid:22480810. http://dx.doi.org/10.1016/j.cden.2012.01.003

12. Brasil. Ministério da Educação. Instituto Nacional de Estudos e Pesquisas Educacionais Anísio Teixeira. Censo da Educação Superior: Microdados do Censo da Educação Superior 2009. Brasília: Inep; 2010.

13. Rosa RS, Oliveira PA, Faot F, Del Bel Cury AA, Garcia RCMR. Prevalence of signs and symptoms of temporomandibular disorders and their association with young university students. RGO - RevGaúcha Odontol. 2008; 56(2): 121-6.

14. Carvalho AL, Cury AA, Garcia RC. Prevalence of bruxism and emotional stress and the association between them in Brazilian police officers. Braz Oral Res. 2008 Jan-Mar; 22(1): 31-5. PMid:18425242. http://dx.doi.org/10.1590/S1806-83242008000100006

15. Rees JS, Jin LJ, Lam S, Kudanowska I, Vowles R. The prevalence of dentine hypersensitivity in a hospital clinic population in Hong Kong. J Dent. 2003; 31(7): 453-61. http://dx.doi.org/10.1016/S0300-5712(03)00092-7

16. Winocur E, Uziel N, Lisha T, Goldsmith C, Eli I. Self-reported bruxism - associations with perceived stress, motivation for control, dental anxiety and gagging. J Oral Rehabil. 2011 Jan; 38(1): 3-11. PMid:20557433. http://dx.doi.org/10.1111/j.1365-2842.2010.02118.x

17. Oderinu OH, Savage KO, Uti OG, Adegbulugbe IC. Prevalence of self-reported hypersensitive teeth among a group of Nigerian undergraduate students. Niger Postgrad Med J. 2011 Sep; 18(3): 205-9. PMid:21980643.

18. Çolak H, Aylıkçı BU, Hamidi MM, Uzgur R. Prevalence of dentine hypersensitivity among university students in Turkey. Niger J Clin Pract. 2012; 15(4): 415-9. PMid:23238190. http://dx.doi.org/10.4103/1119-3077.104514

19. Cunha-Cruz J, Wataha JC, Heaton LJ, Rothen M, Sobieraj M, Scott J, et al. The prevalence of dentin hypersensitivity in general dental practices in the northwest United States. J Am Dent Assoc. 2013 Mar; 144(3): 288-96. PMid:23449905 PMCid:PMC3819160. http:// dx.doi.org/10.14219/jada.archive.2013.0116

20. Tengrungsun T, Jamornnium Y, Tengrungsun S. Prevalence of dentine hypersensitivityamong Thai dental patients at the Faculty of Dentistry, Mahidol University. Southeast Asian J Trop Med Public Health. 2012 Jul; 43(4):1059-64. PMid:23077831.

21. Wang Y, Que K, Lin L, Hu D, Li X. The prevalence of dentine hypersensitivity in the general population in China. J Oral Rehabil. 2012 Nov; 39(11): 812-20. PMid:22882603. http://dx.doi.org/10.1111/j.1365-2842.2012.02334.x 
22. Splieth CH, Tachou A. Epidemiology of dentin hypersensitivity. Clin Oral Investig. 2013 Mar; 17 (Suppl 1): S3-8. PMid:23224064 PMCid:PMC3585833. http://dx.doi.org/10.1007/s00784-012-0889-8

23. Cauás M, Alves IF, Tenório K, HC Filho JB, Guerra CMF. Incidences of parafunctional habits and posturre in with patients craniomandibular dysfunction. Rev Cir Traumatol Buco-Maxilo-Fac. 2004; 4(2):117-24.

24. Kato T, Velly AM, Nakane T, Masuda Y, Maki S. Age is associated with self-reported sleep bruxism, independently of tooth loss. Sleep Breath. 2012 Dec; 16(4): 1159-65. PMid:22146891. http://dx.doi.org/10.1007/s11325-011-0625-7

25. Fernandes G, Franco AL, Siqueira JT, Gonçalves DA, Camparis CM. Sleep bruxism increases the risk for painful temporomandibular disorder, depression and non-specific physical symptoms. J Oral Rehabil. 2012 Jul; 39(7): 538-44. PMid:22506562. http://dx.doi. org/10.1111/j.1365-2842.2012.02308.x

26. Santos-Silva R, BittencourtLRA, Pires MLN, Mello MT, Taddei JA, Benedito-Silva AM, et al. Increasing trends of sleep complaints in the city of Sao Paulo. Brazil. Sleep Med. 2010; 11(6): 520-4. PMid:20494615. http://dx.doi.org/10.1016/j.sleep.2009.12.011

27. van Selms MKA, Visscher CM, Naeije M, Lobbezoo F. Bruxism and associated factors among Dutch adolescents. Community Dent Oral Epidemiol.2013; 41: 353-63. PMid:23121154. http://dx.doi.org/10.1111/cdoe.12017

28. de Siqueira SR, Vilela TT, Florindo AA. Prevalence of headache and orofacial pain in adults and elders in a Brazilian community: an epidemiological study. Gerodontology. 2013 Jun 23. doi: 10.1111/ger.12063. [Epub ahead of print]. http://dx.doi.org/10.1111/ger.12063

29. Rossetti LM, Rossetti PH, Conti PC, de Araujo Cdos R. Association between sleep bruxism and temporomandibular disorders: a polysomnographic pilot study. Cranio. 2008 Jan; 26(1): 16-24. PMid:18290521.

30. Manfredini D, Lobbezoo F. Role of psychosocial factors in the etiology of bruxism. J Orofac Pain. 2009 Spring; 23(2):153-66. PMid:19492540.

\section{CONFLICTS OF INTERESTS}

The authors declare no conflicts of interest.

\section{CORRESPONDING AUTHOR}

Raimundo Rosendo Prado Júnior

Departamento de Odontologia Restauradora, Centro de Ciências da Saúde, UFPI - Universidade Federal do Piauí, 64049-550

Teresina - PI, Brasil

e-mail: rosendo_prado@ig.com.br

Received: November 1, 2013

Accepted: April 8, 2014 